This item was submitted to Loughborough's Research Repository by the author.

Items in Figshare are protected by copyright, with all rights reserved, unless otherwise indicated.

\title{
Geopolitics of search: Google versus China?
}

PLEASE CITE THE PUBLISHED VERSION

http://dx.doi.org/10.1177/0163443716643014

PUBLISHER

Sage (@ the author)

VERSION

AM (Accepted Manuscript)

PUBLISHER STATEMENT

This work is made available according to the conditions of the Creative Commons Attribution-NonCommercialNoDerivatives 4.0 International (CC BY-NC-ND 4.0) licence. Full details of this licence are available at: https://creativecommons.org/licenses/by-nc-nd/4.0/

\section{LICENCE}

CC BY-NC-ND 4.0

\section{REPOSITORY RECORD}

Yeo, ShinJoung. 2019. “Geopolitics of Search: Google Versus China?”. figshare.

https://hdl.handle.net/2134/22421. 


\title{
Geopolitics of Search: Google vs. China?
}

\author{
ShinJoung Yeo
}

Loughborough University London, UK

\begin{abstract}
This paper focuses on the case of Google, the newly emerging US Internet industry and global geographical market expansion. Google’s struggles in China, where Chinese domestic internet firm Baidu controls the market, has been commonly presented in the Western mainstream media in terms of a struggle over a strategic information infrastructure between two nation states - newly "emerging" global power China countering the U.S., the world's current hegemon and information empire. Is China really becoming an imperial rival to the US? What is the nature of this opposition over this new industry? Given that the search engine industry in China is heavily backed by transnational capital - and in particular US capital - and is experiencing intense intercapitalist competition, this perceived view of inter-state rivalry is incomplete and misleading. By looking at the tussle over the global search business, this article seeks to illuminate the changing dynamics of US-led transnationalizing capitalism in the context of China's reintegration into the global capitalist market.
\end{abstract}

\section{Keywords}

Google, Search Engine, Geopolitics of Information, Baidu, Information Empire

Search engine technology is so seamlessly embedded in our daily lives that it masks immense political-, economic-, and social battlefields. While the most frequently propagated notion of the search technology is a tool for "universal access to knowledge" or "equal information access to all," it has grown to become an indispensable component of the world's cross-border information infrastructure, circulating an array of new information, commodities, services and culture over an extraterritorial network - the Internet. Today, the search engine industry sits at the fulcrum of the transnational

\section{Corresponding Author:}

ShinJoung Yeo, Loughborough University London, Here East, off Waterden Road Queen Elizabeth Olympic Park, London, E20 3BS, UK

Email: S.Yeo@lboro.ac.uk 
capitalist market system. It has woven itself not only into the information and communication sectors but also across a wide array of other industries including automobiles, manufacturing, home electronics, health, education, and fashion, reorganizing them into its own profit domains. The search engine is no longer simply an information retrieval system; rather, it is an economic infrastructure for the expansion of transnational capitalist markets as it has positioned itself strategically within the complex and dynamic extraterritorial network of the Internet. Understanding this, it is necessary to ask who shapes and controls this newly emerged critical information and communication infrastructure?

Search, this essential infrastructure for the transnational market system, is dominated by the US-based search engine industry - mainly Google. As this new wave of US information industry is expanding its business profile around the globe, the US seems to be continuing its position of unchallenged information empire, controlling the major information and communication infrastructure as the country maintains and expands its political, economic and cultural influences abroad. However, this has reopened and expanded a geopolitical flash point, revealing the vast unequal structure of information and communication power as the US dominance of this critical information and communication infrastructure is being heavily challenged.

One of the most contested territories for Google is China. China is an interesting case because not merely has it been over the last three decades the world's fastestgrowing economic growth zone ${ }^{1}$ and Internet market by number of subscribers, but also has reintegrated itself into the US-led global capitalist market system. China constitutes a glaring exception to Google’s global market dominance: the home-grown search engine 
firm Baidu holds almost 80 percent of China’s search-engine market by revenue and combined, China's top three search engines Baidu, Qihoo, and Sohu command almost 90\% of the market (Mozur and Tadena, 2013).

Google's struggles in China have been commonly couched in the mainstream media as a battle between Google, the newly “emerging” global power China as a new rival to the current hegemon - the US, the bearer of liberal democracy - and Baidu, representing China’s authoritarian regime. After Google’s partial withdrawal from China due to its dispute over the 2010 censorship and hacking incident, ${ }^{2}$ the Washington Post editorialized, “Google has taken the admirable step of embracing open and public resistance” (2010). The Scientific American called it the "first great clash of the 21st century’s two emergent superpowers-Google and China” (Moyer, 2010).

Is China really a threat to long-standing US global dominance? Is this the signaling of a new information and communication order? What is the nature of this conflict that is roiling this important new industry? By looking at the geopolitics of search through the case of Google and the global expansion of Internet markets specifically in the context of China where Google is uncharacteristically struggling to make headway - this article shows that the understanding of Google in China exclusively as a power struggle between two nation states to control a new strategic information and communication infrastructure is inadequate. I will instead illustrate that the structure of political economy that animates relations between Google, the US, the transnational Internet industry, and China are, in fact, suggestively ambiguous by illuminating the changing dynamics of US-led transnationalizing capitalism. 


\section{Infrastructure of control}

While it is invisible to millions of everyday users, Google's search business is firmly rooted in an extensive material infrastructure, which is a precondition of geographical expansion and capital accumulation. Today, Google has more than 70 offices in over 40 countries around the globe, offers search in more than 130 languages $^{3}$ and makes up almost 25 percent of Internet traffic in North America - bigger than Facebook, Netflix and Twitter combined (Worstall 2013).

Early on, Google understood the importance of network infrastructure in order to operate myriad products - Google search, maps, docs, voice, YouTube, etc. - around the clock and establish its market dominance over the Internet. Since 2005, Google has been acquiring the unused fiber-optic cable called “dark fiber” left dormant by the dot-com crash of the late 1990s and early 2000s (Rowinski, 2013). Securing as much dark fiber as possible is a strategic move because the company can use this fiber to build its own Internet backbone to serve its digital services instead of relying on other telecom firms. The company has to date built 13 mega data centers including in Taiwan, Singapore, Finland, Belgium, Ireland, Chile, and the Netherlands, and has an unknown number of collocation sites where it rents data center space around the world. Google also owns a large private global backbone network including some 100,000 route miles of fiber optic cables, bigger than its rival US telecom giant Sprint's US continental network of 40,000 miles (Fitzgerald and Ante, 2013). Google’s massive commercial infrastructure, as revealed by Edward Snowden’s trove of leaked National Security Agency (NSA) documents, also works hand-in-glove with the US global surveillance regime, feeding untold amounts of data to NSA's programs ${ }^{4}$ (See Guerses et. al in this special issue). 
To further Google’s reach and connect geographically dispersed markets, Google is literally going underwater, participating in building several submarine cables. These include Unity, a Trans-Pacific submarine communication cable between Japan and the US $;^{5}$ a Southeast Asia-Japan Cable (SJC) system called "Faster” which connects China, Hong Kong, the Philippines, Singapore and Brunei with Japan and then runs to the US; ${ }^{6}$ and a newly launched US-Brazil submarine cable project. ${ }^{7}$ With this expansive material infrastructure in hand, Google is establishing its information and communication control and seeking to extend its territory of profit. ${ }^{8}$ However, despite Google’s gargantuan infrastructure, technical and labor capabilities, and financial resources, it has not been able to conquer the world's largest Internet market in terms of number of subscribers and the world's leading growth zone: China.

In China, 632 million people are logged on and spend an average of 25.9 hours a week online (Roberts, 2014). According to the report by China Internet Network Information Center, as of 2014, the country had a little over $47.9 \%$ Internet penetration rate and still has much fertile ground where digital capital can dig. By comparison, the US has about 279 million Internet users and has almost $87 \%$ Internet penetration. ${ }^{9}$ China's Internet economy is larger than that of the U.S. in terms of percentage of GDP, with Internet related economic activities expected to reach 22 percent of the incremental GDP growth expected through 2025 - translating to \$2.28 trillion of China’s GDP (Dobbs, Manyika and Woetzel, 2014). US capital, including Google, desperately wants a piece of the burgeoning Internet sector in the world's fastest growing economy.

In 2006, when Google first entered the meteoric Chinese market, the center of the debate in the US mainstream media was whether Google would compromise its "do no 
evil” corporate principle, and whether Google’s services, even in a limited or censored form, would help to “democratize” China. Despite Google’s self-styled corporate moral high ground, the Washington Post revealed that Google's business interests were at the center of the company's motivation, considering that "the opportunity in China proved too important to resist” (Dean and Delaney, 2005).

For 5 years, before its partial withdrawal from mainland China, Google aggressively built strategic partnerships with major Chinese firms like China Mobile, Qihoo, and Sina, and invested large amounts of capital in Research and development (R\&D). However, Google struggled to gain a foothold while Baidu was able to increase its visibility and maintain its competitive advantage. Google’s dismal revenue generation in China is often attributed to China's state policy heavily favoring domestic capital and censorship by Google itself and the mainstream media, but this offers only a partial answer. To fully understand Google and other US Internet firms' hindrance in China, we must look at the wider context of China's reintegration into the global capitalist economy.

\section{China: Google's Exception}

By the 1980s, China had begun to open its information and communication sectors to transnational capital. But as Zhao asserts, with its entry into the World Trade Organization (WTO), China accelerated its integration into the global market system by reorganizing and expanding its information and communication provision. Unlike most other regions of the world, China has succeeded in building a national information and communication industry that is now tightly interwoven into US-led global informationbased capitalism (2003: 54). 
In the process of shifting to a more state-capital oriented economy, Chinese Party State industrial policy has prioritized its information and communication sectors, treating them as pillar industries of strategic importance, and key economic sectors to link to global capitalism (Zhao, 2008; Hong, 2011). In the 1970s, the post-Mao Chinese Communist party launched a national campaign centered on four areas of “modernization” - agriculture, industry, national defense, and science and technology. Former Chinese President Jiang Zemin once stated, “None of the four modernizations would be possible without informatization” (People’s Daily, 2002). By the 1990s, China had implemented extensive industrial reform policies to develop its domestic information and communication sectors, including the building of special economic zones and statefunded technology parks, supporting homegrown software and hardware IT firms, and investing in state-sponsored large-scale IT infrastructure initiatives (Hughes and Wacker, 2003; Zhao, 2007; Hong, 2011).

Liberalizing its information and communication sectors was thus central to Chinese industrial policy reform, and key to substantial investment by foreign capital over the last 2 decades. Through the terms of WTO accession, many domestic and foreign firms have been able to pursue their mutual interests by giving foreign firms access to the highly lucrative and growing Chinese market, and in exchange giving Chinese firms access to foreign capital (Zhao, 2008: 153). This process is carefully orchestrated by the Chinese Party State, which restricts and controls inflows of foreign capital penetration in its strategic industries including information and communication as a way to nurture its domestic markets (Zhao, 2005; Schiller, 2011). 
Joint ventures, Joint R\&D, and a complex quasi-legal structure called Variable Interest Entities (VIEs) are common vehicles for Chinese firms to access foreign capital and foreign capital to access the Chinese Internet market. Many leading Chinese Internet firms use VIEs as a workaround in which foreign investment is deployed to draw foreign capital into restricted industries without directly controlling ownership. ${ }^{10}$ Via a series of complex contractual agreements with Chinese subsidiaries, VIEs enable the overseaslisted company to effectively run its operations inside China.

The VIE structure is referred to as the Sina-model structure because it was first deployed in 2000 by Chinese Internet company Sina. Major Chinese Internet companies like Baidu, Alibaba, Tencent, Tudou, Sohu.com, and JD.com have been listed on the stock markets in the US, Hong Kong, and Shanghai using the VIE structure (Shaw and Chow, 2011). In 2011, the law firm Cadwallader reported in the Financial Times that 42 percent of Chinese companies listed on the US stock exchange were using the VIE structure, with thousands more unlisted companies operating in the same way (Hille, 2011).

The Chinese Party State is well aware that many of its Internet firms use VIEs to draw in foreign capital, and that foreign capital uses VIEs to invest in the restricted Chinese Internet industry. Yet, for a long time, the Chinese government has maintained an ambiguous policy stance toward them, neither declaring VIEs illegal nor attempting to clamp down on the system and practice. On the flip side, according to a report by the U.S.-China Economic and Security Review Commission, US shareholders in Chinese Internet firms face "major risk" since they do not have ownership control in the event that Chinese courts declare those contractual agreements illegal (Rosier, 2014). One might 
question why the Chinese Party State doesn't take action against VIEs to restrict foreign capital into Chinese strategic industries? Why do US investors continue to invest in Chinese Internet firms in this manner?

For the Chinese government, this ambiguous stand allows for state control at arm's length while effectively maneuvering between national and transnational capital and controlling the flow of foreign capital into strategic industries. Meanwhile, the US government's calling the VIE structure illegal is an attempt to nudge China to further open the Chinese Internet market. At the same time, there is an unspoken understanding among transnational capitalists that the Chinese state is unlikely to take any measures that will negatively affect major Internet firms because too many firms are using VIEs, which involves massive financial stakes across the sector (Pearson, 2012). Alibaba’s CEO Jack Ma, in his talk at the China 2.0 conference in 2011 at the Stanford University Graduate School of Business, assured the audience that the PRC would not regulate the VIE structure given that so many Chinese Internet firms commonly operate as VIEs. ${ }^{11}$ Jack Ma was correct. In early 2015, Chinese Ministry of Commerce released a draft revising its Foreign Investment Law favoring transnational capital by legalizing VIEs in which foreign shareholders are allowed to operate in Internet industries along with telecommunications and education industries (Cover, 2015). The change from the Chinese state was intended to ensure foreign capital's continued investment into China's Internet sectors, signaling transnational capital that it is welcome by the state and safe to operate in China.

Thus, the rise of Chinese Internet firms like Baidu needs to be understood within the context tightly interwoven with the interests of both transnational and domestic 
capital, and domestic and transnational capital classes. However, China is unique in that despite being fueled by transnational capital, the Chinese Party State has grown its own robust domestic information and communication industry which is at the center of its economic development - something that post-WWII Western Europe has failed to achieve - yet intentionally creates seemingly ambiguous regulatory structures that give Chinese Internet firms access to foreign capital.

Both China and the US recognize that transnational capital is so inexorably tied into the Chinese Internet industry that it would be hard to untangle these interests without harming both domestic and foreign capital, including the financial interests of party-state elites. This is not an accidental outcome. Rather, it is the direct result of Chinese state policy as it shifts to a more market-oriented economy, ingesting transnational capital as one of its primary tactics to integrate China into the global economy. Given the extent of absorption of transnational capital into China's Internet sectors, Google and other Internet firms’ struggles in China are more akin to escalated inter-transnational capitalist rivalries attempting to capture newly lucrative markets in economic growth zones.

\section{Baidu Rises}

To understand Google in China, we thus have to make better sense of its intertransnational rivalry with Baidu. Baidu typifies the Chinese Internet industry developed and nurtured by Chinese economic policy, and the entanglements of transnational capital and transnational class interests. Baidu was co-founded in 2000 by Robin Li and Eric Xu, Chinese nationals educated in the United States. In 1999, the two raised \$1.2 million in seed money from Silicon Valley venture capital firms Integrity Partners and Peninsula Capital (Barboza, 2006). With that seed money, Baidu was incorporated in the Cayman 
Islands using the VIE structure. In 2005, Goldman Sachs and Piper Jaffray (PJC), along with Credit Suisse First Boston (CS), underwrote Baidu’s IPO, committing the banks to purchase a certain amount of Baidu shares at an agreed-upon price and listing it on the NASDAQ stock exchange. It was the biggest NASDAQ IPO since the dot-com boom of 2000. At the time of its IPO, the Silicon Valley venture capital firm Draper Fisher Jurvetson - which had also invested in Yahoo!, Skype, and others - owned nearly a third of Baidu (Barboza, 2014). Soon after its IPO, Baidu secured another \$10 million from Draper Fisher Jurvetson and IDG Technology Venture (Barboza, 2006). As of 2014, 84 percent of Baidu's shares were held by 574 financial institutions including US private equity and sovereign wealth funds.

Baidu, as part of its accumulation and competitive strategy, is aggressively building partnerships with foreign companies including Viacom, Dell, Google’s competitor Bing, and Uber as well as with other domestic IT companies. Baidu's domestic competitors include Qihoo, Tencent, and Alibaba, ${ }^{12}$ which all took similar paths as they grew through transnational capital and transnational integration. The Chinese Internet service sector, fueled by transnational capital, has been fiercely competitive, dynamic, and unstable as firms have diversified their accumulation strategies and attempted to move into each other's territories. China's Internet giants Baidu, Alibaba and Tencent are flexing their muscles to maintain dominance in their own domains as well as exerting power to horizontally diversify to extend into the entire Internet space. Yet, similar to US Internet firms, their dominant positions are far from unwavering, facing intense domestic competition as Chinese Internet firms actively search for inroads into overseas markets. 
Baidu’s CEO Robin Li stated that international expansion is an "important way" for the company to spur future growth, as the company searches for profit territories outside China. Baidu is accelerating its global expansion with strategic alliances, with a goal of having its services used by half of the world's population by 2019 (Parra-Bernal, 2014).

Baidu demonstrated its transnational ambitions in 2007 when the company first launched its Japanese services, partnering with Japanese e-commerce giant Rakuten. However, its first foray into global expansion has not gone smoothly. In Japan, Yahoo! dominates the market with over 50 percent market share - although Yahoo! search in Japan is powered by the Google search algorithm and Google also holds over 36\% of the Japanese market (Schaulzer, 2012). As a newcomer, Baidu was not able to make a dent in the Japanese search market against these incumbents. Soon after, Baidu regrouped its global strategies and launched services in Vietnam, Thailand, Egypt, Brazil, and Indonesia to test those markets. These countries may seem randomly chosen, but they are in fact strategic as emerging markets and non-English territories not yet fully occupied by Google and other US firms.

Brazil, one of the most densely populated countries in the world, has led the way for Baidu’s transnationalization efforts. Brazil has the largest Internet population in South America, is fifth in the world with over 107 million Internet users as of 2014 and with a lot of potential growth - 53 percent of its population has access to the Internet ${ }^{13}$ - and US companies have a relatively low presence there. Baidu's strategy in Brazil is not to attract Google users but new Internet users to Baidu. To tackle this potential growth market, Baidu and the world's second largest consumer electronics vendor Lenovo have banded 
together and released the Baidu cloud-powered smartphone. In July 2014, Baidu search went live in Brazil as the Brazilian and Chinese governments made a series of agreements including the creation of a "digital city" in the state of Tocantins funded by the Chinese Development Bank (Mari, 2014). Baidu also recently obtained a controlling stake in Brazilian online-discount company Peixe Urbano to further its push into Brazil as it anticipates that the country’s e-commerce market will be growing 18\% annually by 2016 (Parra-Bernal, 2014).

The Middle East is another region with a burgeoning number of Internet users that is currently under-exploited by capital. In particular, Egypt is considered a strategic market by Internet firms because it is the most populous country in the Middle East and the third most populous in Africa. Kaiser Kuo, Baidu’s director of international communications, told the press that Baidu was not only interested in standard Fusha Arabic script because it is commonly used from the Maghreb to Mashriq, but also that Egypt is considered a culturally dominant country in the Middle East, with a large amount of cultural production and a large number of trained engineers (Mahajan-Bansal, 2013).

What makes these countries attractive markets for Baidu is that the Internet penetration in these countries is still relatively low, so growth is potentially significant. Thus, Baidu is targeting populations and markets not yet fully saturated by US-based capital. So far, compared to its market power in China, Baidu’s overseas operations are relatively small and limited, leading it to seek strategic partnerships to leverage its market power. As a start, Baidu is forging a relationship with a French multinational telecommunications company - Orange S.A., formerly France Telecom S.A. - to provide 
a mobile browser for its Android customers in Africa and the Middle East (Thomas, 2013). Recently the company struck a deal with Microsoft where Bing search engine and Microsoft-owned Nokia will serve Baidu maps to a large number of Chinese tourists abroad $^{14}$ for Baidu outside China.

Meanwhile, Baidu’s US counterparts are not sitting idly by in these markets. Google increased its workforce by 50 percent in Brazil in 2011 as the Brazilian government sought to heavily invest in Internet sectors as a strategy to accelerate and improve the country's social and economic conditions (Pearson, 2011). The company also turned up its profile in the Middle East and North Africa (MENA). In Egypt, during the Arab Spring - the popular struggle that overthrew the US-backed authoritarian regime of Hosni Mubarak and fought for democratic self-determination - Google exploited the story of its marketing executive Wael Ghonim to propagate its own foreign policy of digital capitalism. Ghonim had created the Facebook page "We Are All Khaled Said,” the Egyptian man killed by police, and was himself later arrested and imprisoned for 12 days (Zetter, 2011). Google, and other US Internet firms, backed by liberal western media, portrayed Ghonim as the face of “revolution 2.0," (Vargas, 2012) equating the Arab Spring with the "Internet/Facebook revolution," thereby discounting and undermining a decade of work of Egyptians for their own political and social struggle for justice and crassly promoting their own business agenda. Google’s CEO Eric Schmidt described Ghonim as a hero. Ghonim later worked for Google Ventures before leaving the company to join a start-up.

Shortly after the Arab Spring, Google's calculative business strategy behind the story of Ghonim was made obvious as Google commissioned the Boston Consulting 
Group to conduct market research probing for market opportunities. Google states in its report that "One opportunity Google has embraced is investing in enhancing the quality and quantity of Arabic content on the Internet. The Arabization of the Internet represents a crucial component of Google's strategy in the Middle East and North African region.”15 In that region, Google is enticing elites like Ghonim with start-up funding and programs like "Student Ambassadors” who work as liaisons between Google and their own campuses. ${ }^{16}$ While Google presents this as “empowering” students and providing a “career opportunity,” it is clearly a business strategy meant to extend its market reach by targeting young elites across the MENA region, which is now turning into a battle field for digital capital. As Google gears up to further open the market and search for new profit across the MENA region, does this mean that the company is giving up on China?

\section{Google exits China?}

"We never left China, and we continue to believe in the market. It's a very vibrant Internet market. We have some of the best employees at Google and we continue to grow not only our revenue but also our headcount in the country."

Despite Google’s public claim of moral superiority in its “withdrawal” from China and its ongoing criticism of Chinese censorship, it has never given up on its efforts to gain market share in the world's largest Internet market. In fact, the company quietly turned off its much-publicized anti-censorship service in China after only six months (Clark, 2013).

Google was praised for its "idealistic" act of "leaving” China in protest over Chinese government censorship, presenting itself as the corporate moral vanguard. However, Google has kept its R\&D operations, Google offices and ads businesses in Beijing and Shanghai; in addition, it has never ceased its other business ventures in 
China. Daniel Alegre, Google’s top executive in Asia, alluded to Google’s affirmed new strategy in 2012, saying, “Google is aiming to capitalize on its fast-growing Android operating system for mobile devices, online-advertising and product-search services to grow in China” (Efrati and Chao, 2012). Google’s Android operating system (OS) runs on approximately $84 \%$ percent of Chinese smartphones, while Apple’s iOS has $12.8 \%$ percent of the market (Winkler, 2014). By providing Android OS on many different mobile phones, Google intends to control the smartphone market by driving mobile traffic to Google services.

Given that the majority of cellphones run on Android OS, Google theoretically has a competitive advantage in mobile in-app display advertising in China. Google’s AdMob’s mobile display ads are embedded in more than 300,000 mobile applications (Patel, 2011), and there are more than 10,000 registered Android app developers in China (Lee, 2012). App developers and corporations such as BMW and General Motors are also seeking to leverage Google’s AdMob service, which reaches smartphone users using iPhones and iPads as well as Android devices (Lee, 2012). Most recently, Google has been working to open a local version of the Google Play mobile app store to tap into the Chinese mobile market (Minter, 2014).

These inroads, however, do not mean that the company is succeeding in gaining market share. Not only has Google’s general search market share in China been shrinking, Google shut down its shopping and music services as it was not able to compete with either Alibaba's retail search service eTao or Baidu music. While Google has boasted that the company has more than 900 million devices running Android OS, tens of millions of those Chinese smartphones use only the Android Open Source 
Platform, which does not connect to Google services (Rushe and Arthur, 2013). The major Chinese Internet firms like Baidu, Alibaba and Tencent have all created forked (modified) versions of Android OS, replacing Google services with their own. With this in mind, whether Google can carve out market share in China remains open.

This uncertainty possibly helped to motivate Eric Schmidt to visit China in 2013, when he made a public appearance as a mystery speaker at "Geek Park" - the Chinese version of TED talks - to target product managers, developers and investors. At the gathering of 3000 “geeks,” he spoke about Google’s Android OS, and attempted to persuade local developers to write applications for the platform, enticing them by talking about ways to monetize apps. Schmidt told the crowd, “don’t just settle for the China market. Go after the world market” (Castillo, 2013). He sounded more like a cheerleader than a moralist.

Though the censorship issue has taken center stage in the media, Google CEO Eric Schmidt has demonstrated that he knows the dynamics of the Chinese Internet market. Before launching Google services in China, Schmidt expressed in a confidential presentation that his top concern was local competition (Dean and Delaney, 2005). Unlike most other regions of the world, and even allowing for very extensive financial involvement by US and other foreign Internet firms, US search companies face real intensifying competition from units of Internet capital based in China as the Chinese state’s policies enable and provide maneuverability for domestic digital capital to compete. This has long been a vexing issue for the US government and US capital as they have had limited access to China's booming information and communication industry. And Google and the US government's moralist provocation of China's censorship and 
"Internet freedom” as a human rights issue is a way to pressure China to further open the Internet market for US capital rather than to challenge China's repressive information control to contain anti-capitalist political struggles against the Party State’s expansion of market-oriented economic development.

\section{Google vs. China?}

Do US Internet firms' struggles in China, exemplified by Google, mean that China is a new challenger to the long-standing US global dominance? Or will Google democratize China by offering an "uncensored” search engine, as western media claims? Behind this nation-centric rhetoric, $\mathrm{Wu}$ rightfully posits that there is a "transitional discursive alliance” that exists within and outside China. This alliance consists of the US government, transnational capital, human rights activists, China’s liberal media professionals, public intellectuals, and neoliberal-oriented state officials, who are all allied to promote self-interested capitalist liberal democracy (2014: 446).

As illustrated above, the rhetoric of inter-state rivalry between the US vs. China is undercut by the extent to which transnational capital has invested in China's Internet sector, and conceals the interwoven political economic interests between the two which requires some kind of coordination in sustaining, shaping and expanding global capitalism. Thus, the contention between China and the US is neither about the US's efforts to mobilize the democratic movement to counter China via "new” Internet technologies nor about China's attempts to challenge the US led capitalism. The conflicts between Google, China, and the US are not over whether capitalist development should structure and guide the information sector - or any other sector - but about the terms on 
which this development will proceed. Which companies, which units of capital and which states will dominate and appropriate the greatest share of the profits that result?

The battles will continue between US- and China-based transnational capital over which will occupy a better position in order to control this new site of profit. Yet, the elites in both the US and China have a mutual understanding that transnational cooperation is vital to sustain global capitalism. Their economic interests are tightly enmeshed within the transnationalized global economy, in which information and communication play a pivotal role. In fact, this is far from a hidden political economic agenda.

At the 2014 Asia Pacific Economic Cooperation (APEC) summit in Beijing, President Obama called for greater economic cooperation between the two countries to further both of their interests:

In fact, over recent decades the United States has worked to help integrate China into the global economy - not only because it's in China's best interest, but because it's in America's best interests, and the world's best interests. We want China to do well. We compete for business, but we also seek to cooperate on a broad range of shared challenges and shared opportunities ... Steady, sustainable growth requires promoting policies and practices that keep the Internet open and accessible. $^{18}$

While this rhetoric of cooperation appears normatively benevolent, we should be careful to address what the ends of this cooperation are, and ask the question: the Internet for whom and for what purpose? As Schiller points out, the construction of infrastructure of extraterritorial information networks is pivotal in the expansion of capital and capitalist economies, yet its processes are complex and conflicted given that they are involved with various stakeholders' interests (2011: 90). Google, the US-based Internet empire, and other US capital occupies and controls the strategic high ground of the infrastructure. At 
the same time, the resistance against them from China, which has effectively inserted itself into the global capitalist market, as well as from rival units of capital are intensifying. Yet, to maintain and expand global capitalist economies, these two capitalist states have to negotiate in terms of whether to privilege transnational- as opposed to domestic capital, and which companies will be put in a better position to profit. The case of Google and China, notwithstanding the liberal rhetoric and coverage about "freedom," offers a window into the volatility of the US dominant information and communication illustrating the changing dynamics of global capitalism. However, this does not mean that the US is ceding its leading position; rather, it is retooling and readjusting to accommodate China into the US-led transnationalizing capitalism.

\section{Notes}

1. Recently China has been suffering a sharp economic slowdown with its stock market turmoil and housing market bubble that seems to be in decline, so that it is questionable whether the country will continue to sustain its $10 \%$ average annual growth rate which it has maintained since 1989.

2. In 2010, Google claimed that its computer systems, along with those of 23 other companies, were hacked and that the attack originated in China. Soon after this incident, Google announced that the company was "leaving" China.

3. See Google's description of the company's global reach at https://www.google.com/about/company/philosophy/.

4. Edward Snowden, a subcontractor at the NSA, leaked classified NSA documents revealing that NSA was operating a massive global surveillance program called PRISM. Google and other Internet firms denied having links to the PRISM program; however, it was later shown that NSA had direct access to central servers of US Internet companies. See http://www.washingtonpost.com/investigations/us-intelligence-mining-data-from-nineus-internet-companies-in-broad-secret-program/2013/06/06/3a0c0da8-cebf-11e2-8845d970ccb04497_story_1.html.

5. This submarine cable was built by a consortium consisting of multinational telecom firms including India's telecom service firm Bharti Airtel, Malaysian telecom company Global Transit, US search firm Google, Japanese telecom firm KDDI Corp., Hong Kong based telecom firm Pacnet, and Singapore telecom firm SingTel. 
6. Besides Google, the participants of FASTER include China Mobile International, China Telecom Global, Global Transit, KDDI and SingTel. See https://www.telegeography.com/products/commsupdate/articles/2008/08/26/googlessubsea-ambitions-expand/.

7. Google is partnering with Brazilian ISP Algar Telecom, Uruguayan telcom Antel, and the Angola Cables consortium of Angolan ISPs. This was announced shortly after Brazil declared that it would build a separate cable to avoid NSA surveillance. See the map at https://www.telegeography.com/products/commsupdate/articles/2014/10/13/googlebuilding-us-brazil-submarine-cable-with-three-partners/.

8. The term "territory of profit" is borrowed from Gary Field's work titled Territories of Profit: Communications, Capitalist Development, and the Innovation of G.F. Swift and Dell Computer. Stanford, Calif.: Stanford University Press, 2004.

9. See detailed statistics on Internet penetration rate by country at http://data.worldbank.org/indicator/IT.NET.USER.P2.

10. The VIE structure creates two entities: one offshore and the other in China. An offshore entity is established in the Cayman or other British Islands so that foreign investors are able to inject capital into that entity; in turn they can acquire ownership in offshore assets. The first entity then sets up a wholly foreign-owned enterprise (WFOE) in China as a direct subsidiary. This subsidiary in China sets up one or more domestically licensed companies as its operating companies, and these domestically licensed companies are called VIEs. The Chinese subsidiary sits between the off-shore firms and the VIEs.

11. Stanford Program on Regions of Innovation and Entrepreneurship hosted a conference in 2011 titled China 2.0: Transforming Media and Commerce where Jack Ma and other major Chinese Internet figures spoke at Stanford University. See detailed conference information at http://fsi.stanford.edu/sites/default/files/evnts/media//China_2point0_Agenda_Sept_28.pd f.

12. 60\% of Qihoo's shares are held by Institutional and mutual funds; Alibaba's top five shareholders are Japan-based information technology firm Softbank (32.4\%), US-based internet firm Yahoo! (16.3\%), executive chairman Jack Ma (7.8\%), executive vice president Joseph C. Tsai (3.2), and US-based equity firm Silver Lake Affiliated Entities (2.2\%); Tencent's biggest single shareholder is South Africa's largest media company Naspers with over 33.6\%.

13. See detailed statistics on Internet use in Brazil at http://www.statista.com/topics/2045/internet-usage-in-brazil/.

14. China's outbound travel data available from UNWTO Tourism Highlights, 2014

Edition at http://mkt.unwto.org/publication/unwto-tourism-highlights-2014-edition.

15. See Google commissioned report on Egypt at http://googlepolicyeurope.blogspot.kr/2012/12/boosting-egyptian-economy.html

16. See detailed description of Google's Student Ambassador Program at http://www.google.com/edu/programs/student-ambassador-program/.

17. In 2012, Daniel Alegre, president of the company's Asia-Pacific operations denied that Google had left the Chinese market. See his Bloomberg interview at 
http://www.bloomberg.com/news/articles/2012-01-24/google-china-business-growscontinues-to-thrive-alegre-says.

18. See President Obama's full remarks to APEC CEO Summit at http://www.whitehouse.gov/the-press-office/2014/11/10/remarks-president-obama-apecceo-summit.

\section{References}

Barboza D (2006) The Rise of Baidu. New York Times, 17 September. Available at: http://www.nytimes.com/2006/09/17/business/yourmoney/17baidu.html?pagewan ted $=$ all.

Barboza D (2014) Red-Hot Web in China Richly Rewards Foreign Investors. New York Times, 8 May. Available at: http://dealbook.nytimes.com/2014/05/08/foreigninvestors-reap-enormous-profits-in-chinas-red-hot-internet-market/.

Castillo M (2013) Google's Eric Schmidt tells Chinese innovators to win the world. UpStart Business Journal, 21, February/ Available at http://upstart.bizjournals.com/news/technology/2013/02/21/eric-schmidt-at-geekpark-china.html?page=all.

China Internet Network Information Center (2015) The $35^{\text {th }}$ Statistical Report on Internet Development in China. 4 February. Available at http://www1.cnnic.cn/AU/MediaC/rdxw/2015n/201502/t20150204_51650.htm.

Clark L (2013) Google backtracks on Chinese anti-censorship feature. Wired, 4 January. Available at: http://www.wired.co.uk/news/archive/2013-01/04/google-chinaanti-censorship-fail.

Cover C. (2015) China proposes to change status of foreign stakes in tech sector/. Financial Times, 22 January. Available at http://www.ft.com/intl/cms/s/0/dc6b479a-a211-11e4-aba200144feab7de.html\#axzz3hK9N4An3.

Dean J and Delaney K (2005) As Google Pushes Into China, It Faces Clashes With Censors, Wall Street Journal, 6 December. Available at: http://online.wsj.com/news/articles/SB113468633674723824.

Dobbs R, Manyika J and Woetzel J (2014) China’s digital transformation: The Internet's impact on productivity and growth. McKinsey Global Institute. Available at http://www.mckinsey.com/insights/high_tech_telecoms_internet/chinas_digital_tr ansformation.

Dou E, Osawa J and Ma W (2014) Internet Power Balance Tilts Toward Asia 
After Alibaba's IPO, Four of the 10 Most Valuable Web Companies Will Hail From the Region. Wall Street Journal, 16 September. Available at http://www.wsj.com/articles/internet-power-balance-tilts-toward-asia1410887497.

Efrati A and Chao L (2012) Google Softens Tone on China, Wall Street Journal, 12 January. Available at: http://online.wsj.com/articles/SB100014240529702034369045771550030972775 14.

Fitzgerald D and Ante D (2013) Tech Firms Push to Control Web's Pipes. Wall Street Journal, 13 December. Available at http://www.wsj.com/articles/SB1000142405270230417370457926236188588393 6.

Google vs. China (2010) Washington Post, 14 January. Available at http://www.washingtonpost.com/wpdyn/content/article/2010/01/13/AR2010011302908.html.

Hille K (2011) Foreign internet presence in China to face scrutiny. Financial Times, 1 September. Available at http://www.ft.com/intl/cms/s/2/7f8645e2-d493-11e0-a42b-00144feab49a.html.

Hong Y (2011) Reading the Twelfth Five-Year Plan: China’s Communication-Driven Mode of Economic Restructuring. International Journal of Communication 2: 1045-1057.

Hughes C and Wacker G (2003). China and the Internet: Politics of the Digital Leap Forward. London: RoutledgeCurzon.

Lee M (2012) Google Finally Leads in China -- in App Ad Sales. Bloomberg, 21 August. Available at: http://www.bloomberg.com/news/2012-08-22/google-finally-leadsin-china-in-app-ad-sales.html.

Mahajan-Bansal N (2013) Growth Engine: China’s Search Giant Baidu. CKGSB Knowledge, 12 March. Available at http://knowledge.ckgsb.edu.cn/2013/03/12/technology/growth-engine-baidusglobal-expansion/.

Mari A (2014) Chinese search engine Baidu goes live in Brazil. ZDnet, 18 July 18. Available at http://www.zdnet.com/chinese-search-engine-baidu-goes-live-inbrazil-7000031771/.

McMillan R (2013) Google Serves 25 Percent of North American Internet Traffic. Weird, 22, July. Available at http://www.wired.com/2013/07/google-internet-traffic/ 
Minter A (2014) Is Google going back to China? Bloomberg View, 24 November. Available at http://www.bloombergview.com/articles/2014-11-24/is-googlegoing-back-into-china.

Moyers M (2014) Internet Ideology War: Google's Spat with China Could Reshape Traditional Online Freedoms. Scientific America, 25 February. Available at http://www.scientificamerican.com/article/internat-ideology-war/.

Mozur P and Tadena N (2012) Baidu’s profit Rises, but Concerns Remain. Wall Street Journal, 4 February. Available at http://online.wsj.com/article/SB1000142412788732444590457828492337182471 6.html.

Parra-Bernal G (2014) China's Baidu buys control of Brazil's Peixe Urbano in expansion push. Reuters, 9 October. Available at http://www.reuters.com/article/2014/10/09/us-peixe-urbano-m-a-baiduidUSKCN0HY1EN20141009.

Patel K (2011) Google Takes Mobile Ads to 1 Million More Advertisers. Advertising Age, 7 June. Available at: http://adage.com/article/digital/google-takes-mobileads-1-million-advertisers/235211/.

Pearson R (2012) Looking at Chinese VIE’s. Forbes, 18 October. Available at: http://www.forbes.com/sites/richardpearson/2012/10/18/looking-at-chinese-vies/.

Pearson S (2011) Google’s plan to tap Brazil's fertile market. Financial Times, 22 April. Available at http://www.ft.com/intl/cms/s/2/6fa9386c-6d02-11e0-83fe00144feab49a.html\#axzz2Z9RJdWZz; http://www.chandlernguyen.com/2013/03/search-engine-market-share-mar2013.html.

People’s Daily (2002) Promotion of Information Infrastructure Urged. 27 July. Available at https://web.archive.org/web/20050828222755/http://www.china.org.cn/english/go vernment/37832.htm.

Roberts D (2014) Chinese Social Media Lose 7 Percent of Visitors During Crackdown. Bloomberg Business Week, 22 July. Aavailable at http://www.bloomberg.com/bw/articles/2014-07-22/chinas-social-media-lose-7percent-of-visitors-during-crackdown.

Rosier K (2014) The Risks of China's Internet Companies on U.S. Stock Exchanges. U.S.-China Economic and Security Review Commission Staff Report, 18 July. Available at http://1.usa.gov/1wisq7c. 
Rowinski D (2014) White Spaces \& Dark Fiber: Internet Giants Angle For Control Of The Internet's Pipes. Readwrite, 17 December. Available at: http://readwrite.com/2013/12/17/internet-backbone-google-amazon-facebookmicrosoft.

Rushe D and Arthur C (2013) Google Play Music All Access: search giant launches rival to Spotify. Guardian, 6 May. Available at: http://www.guardian.co.uk/technology/2013/may/15/google-launches-musicstreaming-io-developer-conference.

Schaulzer K (2012) Japan Search Engine Market Share 2013. Search Blog Asia, 15 February. Available at http://www.searchblog.asia/topics/seo/japan-searchengine-market-share-2012/.

Schiller D (2011) Geopolitical-economic conflict and network infrastructures. Chinese Journal of Communication 1(1): 90-107.

Schroeder C (2013) Google and Boston Consulting Group Partner for a Study of a Potential New Internet Economy. 4 February. Available at http:/allthingsd.com/20130204/google-and-boston-consulting-group-partner-fora-study-of-a-potential-new-internet-economy/.

Segal A (2014) The Influence of the Chinese Internet. Council on Foreign Relations, 6 November. Available at http://blogs.cfr.org/cyber/2014/11/06/the-influence-ofthe-chinese-internet/.

Shaw J and Chow L (2011) China VIE structure many hold hidden risk. Financial Times, 11 November. http://www.ft.com/intl/cms/s/2/0a1e4d78-0bf6-11e1-931000144feabdc0.html\#axzz2Pv2dezjE.

Thomas D (2013) Baidu nets France Telecom browser deal. Financial Times, 14 January. Available at http://www.ft.com/intl/cms/s/0/07812948-5d92-11e2-ba9900144feab49a.html\#axzz2aeX9kOP3.

Vargas J (2012) Spring Awakening: How an Egyptian Revolution Began on Facebook. New York Times, 17 February. Available at http://www.nytimes.com/2012/02/19/books/review/how-an-egyptian-revolutionbegan-on-facebook.html?pagewanted=all

Winker R (2014) Google’s Android Begins to Top Out. Wall Street Journal, 2 November. Available at: http://online.wsj.com/articles/googles-android-begins-totop-out-1414972604.

Worstall T (2013) Fascinating Number: Google Is Now Bigger Than Netflix, Facebook And Twitter Combined. Forbes, 23 July. Available at 
http://www.forbes.com/sites/timworstall/2013/07/23/fascinating-number-googleis-now-bigger-than-netflix-facebook-and-twitter-combined/.

Wu C (2014) Inside-Out and Outside-In: The Making of a Transnational Discursive Alliance in the Struggle for the future of China. International Journal of Communication, 8:445-465.

Zara C (2014) With Google, Facebook Blocked In China, Advertisers Turn To Baidu, Alibaba. International Business Times, 14 December. Available http://www.ibtimes.com/google-facebook-blocked-china-advertisers-turn-baidualibaba-1760119.

Zetter K (2011) TED 2011: Wael Ghonim — Voice of Egypt's Revolution. Wired, 5 March. Available at http://www.wired.com/2011/03/wael-ghonim-at-ted/.

Zhao Y (2003) Transnational capital, the Chinese State, and China's communication industries in a fractured society. The Public 10 (4): 53-74. Available at http://javnost-thepublic.org/article/pdf/2003/4/4/.

Zhao Y (2005) The Media Matrix: China's Integration into Global Capitalism. Socialist, 41: 197-217.

Zhao Y (2007) After Mobile Phones, What? Re-embedding the Social in China's "Digital Revolution.” International Journal of Communication 1: 92-100. Available at http://ijoc.org/index.php/ijoc/article/viewFile/5/20.

Zhao Y (2008) Communication In China: Political Economy, Power, and Conflict. Lanham, Md.: Rowman \& Littlefield. 